Ragnar Audunson, Herbjørn Andresen, Cicilie Fagerlid, Erik Henningsen, Hans-Christoph Hobohm, Henrik Jochumsen, and Håkon Larsen

\title{
1 Introduction - Physical Places and Virtual Spaces: Libraries, Archives and Museums in a Digital Age
}

\begin{abstract}
The research that will be presented in this book documents a seeming paradox: in spite of massive digitalization of our everyday lives, libraries, archives, and museums are heavily used as physical spaces and meeting places. The role of LAM-institutions as physical spaces seems to be increasing. Does the massive digitalization we are experiencing lead to a growing need for and appreciation of physical spaces and meeting places?
\end{abstract}

In what direction is our digitalized society steering? Are we heading towards more democracy and more community, due to the forms of crowdsourcing new technologies open up for (Landemore 2013)? Will digitalization lead to increased participation, collaboration, transparency, and thus a deepening and widening of democracy and community, or will it rather result in technologically advanced ways of "talking to ourselves" in increasingly closed circuits of communication or "echo chambers" (Sunstein 2001), i.e. in isolation instead of more community? Will digitalization create new platforms for public discourse and communication between citizens and between citizens and government, or will it result in degradation of public discourse, with mockery and harassment taking the place of rational and respectful arguments? Will it empower citizens or facilitate increased surveillance and a transfer of power from citizens to the state and giant corporations like Google, Facebook and Amazon (Braman 2007)?

From these remarks it might appear that we are standing at a crossroad and that our digitalized society is heading towards the realization of either a dark or a bright vision of the future. However, the contradictory tendencies we have highlighted should not necessarily be treated as dichotomies or mutually excluding scenarios. The development of our digitalized society can be seen rather as multidirectional. It might, for example, simultaneously lead to increased state and corporate surveillance power and increased empowerment of citizens. Developments in the digitalized society might also follow different paths related to the dilemmas and challenges described above. This underscores the scope of opportunities that exists at this juncture for various kinds of actors to influence the direction of development of the digitalized society. To create knowledge and understanding that can help us realize the positive potentials of digitalization and avoid the threats is therefore of fundamental importance. 
In order to shed light on the possible contributions of LAM institutions to the solving of these challenges, this book will address the following questions:

- How is the balance between the digital and analogue roles of LAM institutions, as meeting places and providers of knowledge and information? Is it useful, or even possible, to distinguish between the digital and the analogue, or do they constitute one socio-material reality?

- To what extent do LAM institutions in their policies and practices open for forms of digital user participation?

- What political visions of LAM-institutions as democratic public spaces are currently articulated by European governments and how does digitalization feature in these visions?

- How do professionals in the LAM fields perceive their institutions' roles as democratic public spaces in a digital age?

- What characterizes the public's uses of libraries, archives, and museums in the digital age? What roles do these institutions play in the different life spheres of their users? How do modes of usage shape and form for example libraries and how do new trends in design of libraries change, shape, and form use?

\section{Our Point of Departure}

Libraries, archives and museums have traditionally been institutions empowering their users by providing equal access to knowledge, culture, and information of vital importance. ${ }^{1}$ This holds true even in the present situation, characterized by the ubiquity of the digital. Today, large sections of the population in European countries relate to digital platforms and digital communication in their professional lives, at home, in their social life, and leisure time activities etc. Whereas other institutions of the public sphere, such as printed newspapers, have experienced a dramatic decline in use in recent years, this has not been the case for LAM-institutions. Today, in many European countries, libraries and museums are still used by approximately 50 percent of the population. Our overriding question, then, is: how do these institutions function as public spaces in the digitalized society? Can these institutions be instrumental in realizing what we in another context called "a civilized information society" (Audunson 2001) and what roles do they play in ongoing transformations of the public sphere described above? Such questions are at the base of the studies that are presented in this book.

1 All libraries have traditionally had this role. In this project, however, we will focus upon public libraries. 
As participants of the research project "The ALM-Field, Digitalization and the Public Sphere" (ALMPUB), ${ }^{2}$ the contributors to the book have carried out a broad range of studies of libraries, archives, and museums, in various European countries. The ALMPUB-project comprises research from the Nordic countries as well as from Germany, Hungary, and Switzerland. ${ }^{3}$ A common thread to the studies that have been carried out as a part of the project is a probing of the changing roles of LAM-institutions as public spaces. The book will approach this subject matter from three principal angles: through inquiries into national policies pertaining to LAM-institutions, through inquiries into the professions that belong to these institutions, and through inquiries into the public or users of the institutions.

When engaging with these questions, the contributors to the book depart with an understanding of LAM-institutions as complex public spaces. On the one hand, these are governmental institutions and managed in accordance with the administrative procedures of public bodies. As such, they are instruments for the implementation of central and local governments' cultural and educational policies. On the other hand, libraries, archives, and museums are institutions whose roles and operations to varying degrees are shaped by the interests and needs of their users, or by "the people". Put differently, LAM-institutions are meeting places for the public where the public have played a vital role in setting the agenda and defining their purposes as meeting places. One of the major conclusions from our ethnographic studies of public libraries is that these are multifunctional spaces. In libraries visitors move smoothly and without friction between different roles and life spheres. During one and the same visit they can act in the roles of students, citizens, friends, next of kin etc. (Aabø and Audunson 2012). Fagerlid's ethnographic studies from several local branches of the Oslo public libraries presented in this book dig deeper into the findings of Aabø and Audunson from 2012.

2 In the project we used the acronym ALM, as this is common in Norway. In this book we will, however, use the acronym LAM when referring to the three institutions, as this is common in the international scholarly literature.

3 The selected countries are all undergoing similar processes related to digitalization and globalization but represent different contexts which might be fruitful when studying LAM institutions in relation to the public sphere. Internationally, the Scandinavian countries are regarded to represent a Nordic model and have taken up the responsibility of laying the infrastructural foundations for the public sphere (See Engelstad, Larsen and Rogstad 2017; Larsen 2018). Hungary has, in spite of its socialist past, since the 1970s-1980s developed its public library system according to Scandinavian and Anglo-Saxon ideals (See Audunson 1996; Audunson 1999). Now, Hungarian politics have embarked upon a nationalistic course, which might be relevant for our research questions. In Germany, running costs per capita for public libraries are much lower than in the Scandinavian countries; for example only one fifth in Denmark. Switzerland has its particular public sphere-traditions with frequent referendums. 
Another point of departure for the contributors to the book is an understanding of LAM-institutions as democratic public spaces. This should hardly come as a surprise to readers familiar with academic or political debates on LAM-institutions. Over the last years, the notion that libraries, archives, and museums contributes to democracy in important ways has been foregrounded in cultural policy debates and, increasingly, LAM-institutions have come to profile themselves in this capacity. In the Nordic countries, where many of the studies featured in this book have been carried out, this line of thinking has been elevated into an important - if not the most important - political legitimation for public finance of institutions of the cultural sector. As far as libraries are concerned, this is reflected in recent changes in library legislation in Norway, Sweden, and Finland, focusing upon the libraries' role as meeting place and arenas for debate (Norway), institutions promoting the free formation of opinion (Sweden), and active citizenship and democracy (Finland). We find similar trends within the museum field and the archives field. The topic of the Norwegian national meeting for museums in 2019 was Democracy, Digitalization and Bildung. But is this focus on the LAM institutions' democratic role first and foremost a Nordic phenomenon? In one of the chapters, based on a survey with representative samples of the adult population in all our countries, Hobohm compares German versus Scandinavian attitudes to libraries as institutions promoting democracy.

Our aim in the chapters that follow is to develop analytical accounts of LAMinstitutions' roles as democratic public spaces that go beyond the idealised discourses that are currently in circulation. In doing so, we take as our starting point the fundamental criticism voiced by Paul Jaeger et al. (2013); namely that discussions on the relationship between libraries and democracy lack empirical evidence. According to Jaeger, these discourses tend to proclaim the institutions' role as democratic public spaces more than documenting it. More specifically, the contributors will attend to this task through empirical and theoretical specification of the entailments of LAM-institutions roles as democratic public spaces. Rather than simply affirming that LAM-institutions fulfil important democratic roles, we seek to explicate whether and in what ways they come to fulfil these roles. As a part of this endeavor, we seek also to specify ongoing changes to these roles that are brought on by digitalization, from different empirical and theoretical perspectives.

\section{Libraries, Archives and Museums as Institutions - a Historical Perspective}

Libraries, archives, and museums are organizations and they belong to institutionalized fields. Our study object is the institutions of library, archives, and museum. We are studying changes within these individual institutions (in the 
singular), as well as the institutions seen as a cluster (LAM). Our actual empirical studies are of actors operating within or at the border of the institutions. We study professionals employed within concrete archives, libraries, and museums (organizations), we study individual users of the offering of such organizations, and we study the cultural policies related to libraries, archives, and museums. In the policy studies, the authors have analyzed concrete policies related to both the institutions in the abstract, and to concrete organizations, such as the national library or the national archive. When wielded together, the individual studies provide an understanding of ongoing changes within the institutions of library, archives, and museum. ${ }^{4}$

Libraries, archives and museums have developed historically as institutions from common roots (Given and McTavish 2010). They are all closely linked to the nation building project of the eighteenth and nineteenth centuries, which needed museums and libraries to document the national culture and archives to establish efficient administrative and governmental procedures; they are linked to the age of enlightenment which needed institutions to spread knowledge also to lay people; they are linked to the growth of the bourgeois public sphere, also in the late eighteenth and early nineteenth centuries and they are linked to the development of modern universities according to the norms of Humboldt. Modern science and the search for knowledge presupposed institutions where academics could have access to the works of other academics, thus contributing to establishing a system of scholarly communication. In some instances, they made up one integrated organization. The British Museum was the library where Karl Marx in the middle of the nineteenth century was sitting when writing Capital. The British Library was singled out as an independent institution as late as 1973.

Libraries, archives, and museums have in common that they have been important institutions of the public sphere of modern societies. More specifically, libraries, archives, and museums are similar in that they take on four important roles: they are memory institutions guarding our collective and public memory, our cultural heritage. As memory institutions, they provide knowledge and cul-

\footnotetext{
4 According to American sociologist W. Richard Scott, "Institutions comprise regulative, normative, and cultural-cognitive elements that, together with associated activities and resources, provide stability and meaning to social life" (Scott 2014, 56). This definition can be directly applied to the institutions under analysis in our book: most people know what a library, an archive, or a museum is and what one usually does when present at one, simply by hearing the word spoken in a sentence (cultural-cognitive). Most of us think that these institutions should be public and accessible, as part of our democracy (normative). These institutions are regulated in certain ways by public bodies though cultural polices (regulative). Due to the cultural-cognitive, normative, and regulative aspects of our institutions, they tend to be similar across national borders.
} 
tural expressions to large sections of the population. Libraries, archives, and museums have exerted and continue to exert as agents of popular enlightenment, and they have a role as local meeting places and arenas of participation in public space.

Even though there are important commonalities between libraries, archives, and museums and in spite of them frequently being subsumed under the joint category of memory institutions, they are simultaneously constituted as separate institutional fields via for example institution specific educational programs, institution specific professional organizations, conferences, journals, institution specific legislation etc. This institutionalization of a library, and an archival and a museum field might demarcate the LAM-institutions from each other. Vårheim, Skare and Stokstad's analysis of the rise and fall of the Norwegian LAM authority in this volume illustrates this.

Realizing the public potential in artefacts carrying knowledge and cultural content otherwise locked in private collections and securing public access to these collections is in many ways the basic idea and raison d'être of libraries, archives, and museums. They have actively strived to reach all segments in society and mediate the content of their collections to all social strata. Taking libraries as an example, the American library historian Wayne Wiegand documents how public libraries from the very start served as arenas integrating also groups who did not have access to other public sphere arenas, e.g. workers, women and teens. ${ }^{5}$ As a corollary of this, libraries, archives, and museums have been public meeting places open to wide sections of the populace. A wide range of meetings and debates open for all took place in libraries already in the first decades of the twentieth century and Wiegand documents how the public from early on had an influence over the agenda of their local library. The role of libraries in their communities, e.g. the balance between popular fiction on one hand and high-quality fiction and non-fiction on the other, were always a negotiated compromise between the librarians and the citizens of the community the library in question served (Wiegand 2015).

When the modern idea of public librarianship was implemented in European countries, it was naturally moulded and adapted to different national contexts, for example the impact of the popular movements in Sweden, the broad movement of popular colleges in Denmark, the struggle for independence from Sweden in Norway, and, in all the Nordic countries, the dominating position of the social democratic welfare state from 1945 and onwards. In Germany, Hungary, and Switzerland, other national trends and traditions had impact on the implementation of

5 The integration of colored people is more doubtful. In the southern states of the US, public libraries were also segregated. 
the public library model in particular and the development of LAM institutions in general. For example, in Germany the dominating party in establishing the German welfare state in the first decades after WW2 was CDU, a relatively conservative Christian-Democratic Party (van Kersberger 1995), as opposed to the social democratic parties of the Scandinavian countries, which kept socialism as a programmatic vision well into the latter half of the 1970 s. $^{6}$

The modern concept of a public library was in Norway implemented by Haakon Nyhuus, library director in Oslo from 1898 onwards. In the years immediately preceding the appointment of Nyhuus, annual circulation in Oslo's public library varied between 20,000 and 30,000 per year, i.e. from 0.09 to 0.13 volumes per inhabitant. In 1900, when Nyhuus had been in office for two years, that figure had exploded into 310,000, i.e. 1.2 volumes per inhabitant. In 1915 that figure had more than doubled to 660,000 volumes, i.e. 2 volumes per inhabitant yearly. These figures illustrate the crucial role of the library in integrating ordinary people - women as well as men, workers as well as middle class, youngsters as well as adults - in the public and that libraries have been important in establishing a literary public sphere.

Museums were vital in creating one basis for a unified national discourse a national and cultural identity - by giving citizens access to the national cultural heritage. Early museum collections were first established for facilitating scientific enquiry, and not primarily for public access. In the nineteenth century, museums were also used as instruments for creating one basis for a unified national discourse, a national and cultural identity. To this end, museums of cultural heritage and history of industries and the like have developed collections in order to preserve buildings and other cultural heritage objects which were about to disappear from the rural scene and modern way of life. Exhibitions open to the public had partly other origins than the endeavors of creating museum collections, such as oddities, entertainment events, or the world exhibitions from the mid-nineteenth century onwards. Museums as places for exhibitions and dissemination of knowledge to the public followed suit. The Norwegian Folk Museum was established in 1894, and Bergen Museum established the first permanent building for exhibitions in Norway in 1897. In modern society, most museums combine a scientific approach with preservation of heritage and outreach activities. Their mission as institutions for the public can be taken for granted.

6 In spite of these differences, there were fundamental similarities. Haakon Nyhuus, the Norwegian public library pioneer, and Szabo Ervin, who implemented the modern public library concept in Hungary early in the twentieth century, never communicated as far as we know. Nevertheless, they had the same reform ideas and implemented the public library ideas stemming from the United States at approximately the same time (Audunson 1996). 
Archives and the archivist profession deal with what is sometimes called the secondary value of archival materials. The primary value is to evidence actions and events. The secondary value is as information and heritage and is often able to shed light on aspects of past events beyond the intended purpose of the records. The archivist profession has traditionally been regarded as an auxiliary profession to the historians. Early dissemination activities have been directed towards the professional community, such as printed editions of transcribed ancient diplomas. Since the early twentieth century, there has been a modest expansion of the user communities to include amateur historians and genealogists. However, the threshold for finding and interpreting old handwritten materials remained too high for the larger public. Reaching out to the general public is therefore, generally speaking, a more recent aspiration for archives than for libraries and museums. Access to archival materials, and outreach as part of the archivists' professional repertoire, has predominantly expanded to the general public and gained momentum through digitalization of much sought sources. Outreach programs and physical events prepared by archival institutions may not necessarily be a direct result from digitalization as such, but their recent growth have likely been stimulated by the increased demand and visibility instigated by the archives' digital presence.

The development of libraries, archives, and museums has not been a unilateral top-down process structured by governmental and professional authorities. Popular movements have also been active in establishing and running libraries, archives, and museums. In the Nordic countries, public libraries in their formative years were closely associated with democratic popular mass movements such as the trade union movement, the temperance movement the folk high school movement, and countercultural movements representing the linguistic, cultural, and religious periphery against the elites of the centre. Voluntary work and the effort of local enthusiasts have often been important in creating and running local museums. Although archives at a national level are relatively strictly regulated and governed via law and governmental authorities, local enthusiasts and local associations such as local history associations have often been instrumental in establishing local history archives, as have popular mass movements such as the labour movement and the temperance movement.

Focusing upon libraries, Söderholm and Nolin identify three historical waves of community engagement. In the early twentieth century, during the first wave, the focus was upon literacy and public education, the second wave in the late 1960s and 1970s focused upon "radical” grassroots work for targeted social inclusion, while the third wave which took off around 2000, and still lasts, focuses upon community hubs, open social space, and diversity (Söderholm and Nolin 2015, 253). In an adapted form, these three waves are probably also valid for mu- 
seums (see for example Simon 2010) and - with some hesitations - for archives as well. The upsurge in interest in genealogical research and, not least, the upsurge in interest in local community research is reflected in the high number of participants in the local history wiki which Erik Henningsen and Håkon Larsen present in one of the chapters in this volume. In accordance with Söderholm and Nolin, these processes should be viewed as cumulative or sedimentary. In the transition from one historical wave to another, the focus and values of the former wave is not left behind or replaced by new values but becomes an integrated part of an extended social role. Literacy and public education, for example, remain important elements in the social role of the LAM-institutions even today.

\section{Theoretical Perspectives}

From this brief historical account, it should be clear that one reason for describing libraries, archives, and museums as "democratic" public spaces is that they contribute to the empowerment of people. To provide broad sections of the population access to information, knowledge, and cultural expressions has been - and continues to be - a core mission of LAM-institutions. By gaining access to these resources, people become better equipped to exert citizenship and in other ways to participate in society. A survey undertaken in our six partner countries (Norway, Sweden, Denmark, Germany Hungary, Switzerland) clearly documents that libraries as well as museums and archives are used in these ways today. As documented in another publication from the ALMPUB-project, a high proportion of the users that responded to the survey reported that libraries, archives, and museums sometimes or often are important sources for accessing citizenship relevant information - information regarding their rights and obligations as citizens, keeping themselves generally updated as citizens, informing themselves in issues they are particularly interested in as citizens, and making decisions as citizens. Here we find the highest proportion among the users of archives, where more than 60 percent report that they access such information in archives (Audunson et.al. 2019b). However, when we describe libraries, archives, and museums as democratic public spaces in this book, this points beyond the roles these institutions take on as (publicly accessible) repositories of information, knowledge, and cultural expressions. It points also to the institutions' role as arenas of public action and interaction. How can this aspect of LAM-institutions' roles as democratic public spaces be grasped theoretically?

When dealing with this question it is essential to sort (scientific) explanation and analysis from political legitimation. Public libraries, archives, and museums differ when it comes to their legitimating purposes. A national art museum is there 
to document the national art heritage and promote knowledge and experience related to that. A natural history museum is there to document the development of the natural history and promote knowledge and experiences related to that. Archives are there to document decision-making processes, administrative procedures, and case handling of public institutions. Public libraries, however, tend to have more porous legitimations related to a multiplicity of life spheres and policy areas. The public library, therefore, although a remarkably durable institution, tends to have its raison d'être continuously questioned. Documenting its value is challenging (Huysmans and Oomes 2013). A range of justifications have been offered seeking to connect libraries with trending topics relating to their respective social context: they may be "media-lending facilities", "information facilities", "agencies for freedom of opinion and information", "learning centres and educational institutions", "cost centres with high return on investment", "analogous places in digital dematerialisation" or, more recently, "communicative places for democratic opinion formation". This results in evolving justifications linked to current trends which seek to explain why libraries exist, generally while convincing funding bodies of their legitimacy. The most striking aspect of these arguments - even as they actually appear in mission statements, strategy papers, and library laws - is their fundamentally normative nature.

Policy often lacks the kind of empirical underpinning that could provide arguments based on current practice or its historical development with facts. Alternatively - or additionally - no theoretical justification has been developed by any discipline - political science, economics, sociology, anthropology etc. - capable of providing the well-argued conceptual framework for analysis and thought required to explain why the library institution is actually needed, and why it seems to have continuously endured despite all adversities during all time periods and in all forms of society and institutions. ${ }^{7}$ The normative framing of the library's role is particularly noticeable in library laws, which also serve as an excellent barometer for observing social cycles and cultural contexts. Here, "social integration enabling democratic participation" ${ }^{\prime}$ is mentioned with increasing frequency. In

7 This prompted leading representative of the American Library Association (ALA) Michael Gorman (2015) - to take just one prominent example - to express his astonishment that, 15 years after the first edition of his famous "manifesto" "Our Enduring Values", the library (be it "public" or "academic") has yet to lose its importance despite the emergence of so many technical upheavals and innovations (from Google to smartphones and social media) in recent years. It continues to demonstrate its "enduring values", especially in critical periods which Gorman links explicitly to the role of libraries in democracy. However, his evidence remains anecdotal and is taken as an article of faith (cf. Marci-Boehnke 2019).

8 E.g. in one German State Library Law we read: "Sie [Bibliotheken] sind Orte der Wissenschaft, der Begegnung und der Kommunikation. Sie fördern den Erwerb von Wissen und damit die 
Europe's Nordic countries, the extent to which culture and library legislation assigns libraries a responsible and active role in democracy is striking (see page 3 earlier; see also Audunson et al. 2019b). ${ }^{9}$

Habermas' Structural Transformation of the Public Sphere (1989[1962]) has had a strong and lasting impact in the Nordic countries. The book was translated and reviewed relatively early in the Nordic countries, while Anglo-American discussion around the "public sphere" began much later due to a delayed translation into English. Perhaps this also explains Habermas' late, but in recent years all the more hotly disputed, reception in international library science (e.g. Buschman 2003, 2019; Jaeger and Burnett 2010; Vårheim et al. 2019; Audunson et al. 2019a). Habermas views the free opinion forming, non-hierarchical discourse and bourgeois public sphere, which he observed at the beginning of the eighteenth century in the "communities" of the municipal cafés and reading societies, as the prerequisite and basis for democracy. In contrast to Michel Foucault (2005[1966]), he does not focus on libraries as places for the formation of a democratic public sphere or indeed even as "special places" (Foucault's heterotopia). It should be noted that the Anglo-American discourse of library science has yet to incorporate many of the other French reactions to the Habermasian theses on democratic consensus-culture which may cast a different light on some current, rather less consensual (some say democracy-damaging (Helbing 2015)) excesses in the digital public sphere (see Huzar 2013; Lyotard 1988; Rancière 1999).

Even if theoretical discussion of the political role of libraries was on the increase long before David Lankes (2011), empirical research on libraries and the public sphere is limited (Widdersheim and Koizumi 2016). So far, only a few studies have yielded concrete research results in the spirit of evidence-based librarianship (Booth and Brice 2004). Alex Byrne has established a clear correlation be-

\footnotetext{
gesellschaftliche Integration und demokratische Teilhabe.” §1 LBibG des Landes RheinlandPfalz (19.11.2014) (translated quotation: "They [libraries] are places of science, interaction and communication. They promote the acquisition of knowledge, thus enabling social integration and democratic participation.")

9 The fact that this idea is actually a well-established claim within library science can be seen in this quotation of the German librarian Hans P. Schuhböck dating from the 1980s, which continues to be cited internationally: "A yet-to-be-undertaken attempt to derive the function of the library from the characteristics of a democratic society would have to take the two sides of the relationship between society and state in modern society as its starting point: welfare state and popular sovereignty, with the democratic public sphere mediating between state and society" (Schuhböck 1983, 222 translated from German). Jürgen Habermas' habilitation thesis "Strukturwandel der Öffentlichkeit" ("Structural transformation of the public sphere”, 1989[1962]) was important for making the concept of the public sphere central to democratic theory, with its ideal of a "domination-free discourse" (for a critic from a digital age perspective, see Han 2013).
} 
tween the democratic maturity of a country and the existence and use of libraries worldwide. Based on the "Democracy Index" of the Economist Intelligence Unit (EIU) and the Library Map of the World of the IFLA, he even postulates a "symbiotic relationship" between libraries and democracy. The correlation coefficient is particularly high when political participation of users is accounted for, and less when controlling only for the mere existence of a library infrastructure.

Michael Widdersheim (2018) has applied methodically sound case studies with solid empirical foundations to investigate how public libraries develop into different political cultures over a long period of time. On this basis, he formulates a "political theory of library development" that describes the requisite and adequate factors for change in public libraries. Like all publicly financed infrastructure, libraries' development - i.e. their adaptation to the changes in society and its supporting institutions - is governed by a cycle of political decisions. Libraries can be said to perform best (and achieve successful development) when they demonstrate responsiveness by reacting to external developments, even if in the normative framing of their funding bodies these have yet to be implemented specifically to libraries. Interesting conceptual analyses from Michael Widdersheim and Masanori Koizumi have been able to illustrate the recent diversity of development in the field of research "Libraries and Democracy" (Widdersheim and Koizumi 2016).

The abovementioned survey from our six partner countries clearly confirms that libraries as well as museums and archives offer services and are used as public spaces along the lines of Habermas' theory of the public sphere. ${ }^{10}$ Here, a substantial proportion of the users of libraries, archives, and museums report that they have attended public meetings, lectures, and debates at these institutions (Audunson et.al. 2019b). Ethnographic studies from public libraries undertaken as a part of the ALMPUB project also highlight the role public libraries take on as arenas for respectful discourse, but not necessarily with an aim of reaching a common opinion. ${ }^{11}$ Thus, in Fagerlid's study of social reading circles at libraries, similarities appear between these groups (that mainly consist of women) and the

\footnotetext{
10 According to Habermas (1989[1962]), the public sphere is a sphere in-between and independent of the private sphere, the market, and the state. In the public sphere, citizens come together to discuss issues of common interest and a public opinion can be formed. The public sphere is a sphere where rationality prevails, and the participants are committed to the value of the better arguments. It is an open sphere, where participants meet on an equal footing - as citizens - not according to rank and status in a hierarchical system.

11 Our research indicates that the Habermasian understanding of the public sphere as an arena for forming a public opinion rather should be rephrased as an arena for forming public opinions, i.e. stressing the plural. Through a civilized and respectful public discourse, we refine the opin-
} 
literary salons of the early days of the developing bourgeois public sphere. However, as a framework for understanding what goes on between people at libraries, archives, and museums, Habermas' theory on the public sphere has clear limitations. In part, this is due to the theory's strong dualistic and rationalistic leanings that give little credence to the emotional, affectual, and sensuous aspects of experience and communication. Rather than rational minds in minimalist bodies like the Habermasian subjects (Gardiner 2004, 31), people visit museums and libraries as gendered, socially situated, experiential, and affective human beings. In daily life, rational and emotional, individual and social, private and public needs and concerns often blur. For example, a lonely elderly man reads the newspapers every day in the library in order to stay informed or to be among people. In our survey among professionals in the three fields (Audunson, Hobohm, and Toth, this volume), respondents in particular from the museum field were of the opinion that creating emotional involvement and engagement via the museums' exhibitions was more important than providing a background for a rational discourse via neutrally curated exhibitions striving for balance.

Furthermore, while the ambition to facilitate a salon public features prominently in policy discourses in the LAM-field, and in the event-programming of libraries, archives, and museums, the survey indicates that this is accorded low priority by users as well as professionals. Here, users rank the libraries' role as arenas for public discourse close to the bottom among 12 reasons legitimizing the use of scarce public resources for upholding a library service. Although an overwhelming majority of librarians, archivists, and museum professionals report that arranging public meetings and debates are important parts of the service portfolio in their respective institutions, they rank these activities relatively low compared to other reasons for upholding their service.

The findings referred to above on libraries as democratic meeting places illustrate the importance of side effects (Elster 1981). The role of libraries as meeting places and democratic spaces plays a prominent role in library policies and strategic documents. But the users frequenting a library, an archive, or a museum do not frequent an abstract "meeting place." They go for an experience, to find a book, to work, to relax, to search for a piece of information they need in their everyday lives, to read newspapers, to listen to an author or to be with others - in short, they visit the library to satisfy individual needs and interests. The library's role as a democratic community-building meeting place is a side effect. Nevertheless, in our qualitative observations, as well as our survey, we find that libraries are important places for a variety of meetings and encounters.

ions we started out with, and we learn to respect and accept the opinions of others, but we do not - maybe we should add hopefully not - develop a, in the sense of one, common opinion. 
Another theoretical angle we will rely on to grasp LAM-institutions' roles as democratic public spaces is to view these as arenas for the formation of a culture of civility. This directs us to a cluster of theories that are less concerned with the formation of public opinion than with the multiplex forms of interactions that go on between people at public places and the skills or competence in dealing with social and cultural complexity they acquire through these experiences. Thus, according to Sennett $(1977,2009)$, the public realm is to be considered a place where strangers meet and where they can become part of a culture of civility. To Sennett, the public realm is a forming space where people are developed as tolerant citizens. Sennett can be read as delivering a defence for re-establishing social conventions, which best can be relearned in the public space, whether in the street, in the café or in cultural institutions such as libraries, archives, and museums. The re-establishing of the social conventions is not to be looked upon as a sort of rigid armour to hide or enclose the subject, but on the contrary as a condition for people to enjoy the company of each other at the same time as they are protected against more unfortunate inclinations of others (Rasmussen, Jochumsen, and Skot-Hansen, 2013). Strauss (1960), Lofland (1973), and Klinenberg (2018) make similar arguments regarding the civic skills people acquire from participation in public places, including libraries and museums. These skills are essential prerequisites for a well-functioning democracy in societies characterized by social divisions and cultural diversity. That LAM-institutions are arenas for the formation of skills of civility has been well documented in previous research (Audunson 2001) and the fruitfulness of this approach is confirmed by qualitative and quantitative studies undertaken as a part of the ALMPUB-project. In the survey that was carried out within the framework of the project, we found that among the users of libraries, 40 per cent of the respondents reported having entered in contact with strangers, for example via short conversations, and every fourth library user reported such contact with strangers belonging to a group different from themselves, e.g. a different age group, a different ethnic group (Audunson et al. 2019b).

A third theoretical angle we rely on in the chapters that follow is to consider LAM-institutions as arenas for the formation of community. This directs us to theories that may overlap considerably with Sennett and the other writers listed above, but that differ in that they give less emphasis to the formation of skills of civility than to the ways in which people may enter into communities and attach a sense of "home" to public places. In his book The Great Good Places - Cafés, Coffee Shops, Bookstores, Bars, Hair Salons and Other Hangouts at the Heart of a Community, the American sociologist Ray Oldenburg describes, analyzes, and praises the different places where people can gather, put aside the concerns of home and work, and hang out for the pleasures of good company and lively conversation. 
Nevertheless, according to Oldenburg these places are not without a more serious meaning as they actually are the heart of a community's vitality and the grassroots of a democracy (Oldenburg 1989). Oldenburg names these places "third places", contrary to "first" and "second places", which are respectively home and work. Unfortunately, according to Oldenburg the third places have been declining in postwar USA.

The prevailing successful paradigm of the library as a "third place" is, on the one hand, indicative of the current "state" of society and its search for a community in the digital world (Stalder 2018) beyond the intimate private sphere and the world of work governed by outside forces (Oldenburg's first and second places). In view of the issues which clearly extend beyond these two spheres, there is a growing awareness that participation in the processes of civil society can no longer only take place passively behind (television) screens, and that more than the fourth estate of journalism is needed (Fichtelius et al. 2018). On the other hand, current trends speak for themselves: new third places (such as co-working spaces and maker spaces) are emerging but their effects and even causes are difficult to measure. In empirical terms, it remains unclear why libraries are now being promoted by politicians in line with the described current trends of third place development and the support of a civic public sphere. ${ }^{12}$

Library professionals have widely adopted the concept of "third places". Our research, both the quantitative surveys and the observational studies, document that libraries do function as third places. Thus, Evjen and Vold, who have studied a dedicated branch for children and youngsters between 10 and 15 years of age in an Oslo public library, conclude in their chapter in this volume that this branch first and foremost functions as a third place. This is interesting taking into consideration that Oldenburg himself does not consider libraries as third places as they are often too big and too purposive. Nevertheless, the comprehensive articulation of "third places" in library circles has undoubtedly helped to create greater focus on the library as meeting- or community space when rearranging old libraries or building new. What is particularly interesting in this context is that we have witnessed, during the last decade, an increased interest from museums to become "third spaces", inviting users to stay longer and engage with each other (Tate 2012). Our studies, however, indicate that the concept of third places, although important, is too narrow to grasp the complexity of the library's role in the same sense as we have argued that the public sphere concept also is too narrow. Library use is simultaneously linked to the users' private lives, i.e. first place,

12 Danish library policy seems to be the exception which proves the rule here: the frequently imitated example of the municipal library of Aarhus DOKK1 reveals exactly how successful evidencebased library development can be (Jochumsen 2018). 
to work and education, i.e. second space, and to community, i.e. third space. We need concepts and approaches that can grasp this complexity and should refrain from perspectives narrowing it down.

Participation, user empowerment, and community orientation are often key elements of observed paradigm changes in the professional fields of LAM. Let it be called "New Librarianship" (Lankes 2011) new currents of archival thinking (MacNeil and Eastwood 2017) or "New Museology" (McCall and Gray 2013). Especially in New Librarianship, the concept refers to the cybernetical (i.e. digital) foundation of knowledge in society: only via an interaction of information agents, a "conversation", may knowledge occur in a community (Lankes 2011). This reflects quite well the conception of our digital age by the Swiss media scientist Felix Stalder (2018), who defines "digitality” by its three dimensions: algorithmicity, referentiality, and community.

Change versus stability is a central issue in the research on which this book is based. How do technological changes induce change and do the role and social mission of the LAM institutions change or remain stable when exposed to digital changes? Institutional approaches are fruitful when discussing such processes. When Henningsen and Larsen analyze policy documents on digitalization of LAM-institutions in Norway (this volume) and coin the term "digitalization imperative", they are, among other things, identifying institutional isomorphic processes. When Vårheim, Skare, and Stokstad (this volume) use historical institutionalism to analyze the rise and fall of the ALM-authority in Norway between 2003 and 2009, they are identifying encultured and institutionalized norms and standards promoting or prohibiting convergence.

\section{Libraries, Archives, and Museums in the Digital Age}

Technology changes the way we live and permeates every life sphere. The ubiquity of online searching is a fundamental characteristic of our way of living (Haider and Sundin 2019). Digitalization has fundamentally affected the public's media use. The proportion reading traditional newspapers and watching traditional television has fallen dramatically. Many have foreseen that also LAM-institutions will lose ground due to digitalization. According to Nicholas (2012), digitalization leads to a situation where people do not need librarians (or archivists or museum professionals) as intermediaries. Via the Internet, we have all direct access to the resources, which in the pre-digital era were guarded by librarians, archivists, and museum professionals.

The omnipresence of digital technologies and their supplanting of traditional physical meeting places is, however, not unambiguous. In spite of Massive Open 
Online Courses (MOOCs) and digital learning platforms, universities are very preoccupied with physical campus development - a seeming paradox in a situation where it is technologically possible to complete a degree without setting your foot on campus. Universities, in spite of this, continue to invest billions and billions in physical campus development, while in their rhetoric being preoccupied with what they term "digital transformation". A similar trend is in evidence in the LAMfield in the Nordic countries and other parts of Europe. In parallel with the massive digitalization, large investments have been made in recent decades in museum and library buildings, often of a spectacular nature. To take one example, through ongoing developments of the seaside parts of the city centre of Oslo, this area is about to become plastered with monumental buildings housing cultural institutions. This and other trends in the cultural sector prompt the question of whether digitalization and the ubiquity of social media create a newfound appreciation of our need for physical meeting places. Is there a dialectic at work here, whereby the increasing digitalization of everyday experience heightens the awareness of the value of tactile experiences and face-to-face human communication?

This question, which is perhaps one of the most important coming out of our research, serves as a reminder of the critique of "telepresence" Hubert Dreyfus formulated in On the Internet (2009[2001]). Here, he argued that digitally mediated experience is not only inferior to face-to-face communication when it comes to learning and skills acquisition, but more broadly as a vehicle of human engagement with the world. What is lost on the Internet, according to Dreyfus, is embodied experience and engagement with people and things. With this loss of bodily involvement, we lose the sense of risk and vulnerability that attaches to our engagements in the real world, the sensitivity to shared moods that make social situations matter to us and, ultimately therefore, the sense of being connected to reality. To live one's life on the Web, Dreyfus notes, may be attractive to people because it is a path of least resistance that relieves them from the vulnerability and commitment of real world involvements with people and things, but at the same time "this lack of passion necessarily eliminates meaning as well" (137). Thus, on this account, if one is to live a meaningful life, one would have to embrace "our embodied involvement in the risky, moody, real world" (120). If one accepts this argument, the expectation follows that the massive digitalization of everyday life that has occurred in recent years would probably engender a widespread appreciation of, or need for, experiences of face-to-face human interaction and experiences of real physical places.

The findings of the ALMPUB-project support this assumption. Based on our research we can conclude that libraries, archives, and museums are heavily used also in our digital age and that they first and foremost are used as physical spaces, not digital. Contrary to the prophesies of the vanishing of libraries, archives, 
and museums, these institutions have not suffered the same fate as for example newspapers. A survey undertaken within the framework of this project in the six partner countries confirms that particularly libraries and museums are used by a majority of the population and that physical visits dominate, although physical use is combined with the use of digital services. The proportion of the population that report having visited a museum over the last 12 months has not been reduced since the 1990s and the proportion visiting libraries and using them as meeting places seems to be increasing. In Norway, Sweden, Denmark, and Hungary, a clear majority of the respondents have used libraries one time or more in the preceding 12 months. In Germany and Switzerland, the percentage of users is not very far from 50 (Audunson et al. 2019b). These figures are in line with most surveys measuring library use. A majority in all the countries have visited a museum one time or more, whereas the proportion using archives at least one time per year varies around 20 in all the countries. The most important difference in use patterns between libraries and museums, which also our research confirms, is that a significantly larger proportion of library users visit the library frequently $-3-4$ times per year or more often - compared to users of museums.

In addition to LAM-institutions' strong position as physical meeting places, libraries, archives, and museums have gone digital. They have made their content accessible via digital platforms, having developed digitally based forms for user participation and digitally based platforms for communication with the public. New arenas for public life have emerged within and across LAM-institutions, e.g. in the form of crowdsourcing or voluntary digital work. Thus, in one of the chapters of this book, Henningsen and Larsen show how a local history wiki site operated by the Norwegian National Library has become a vehicle for public expressions by local history enthusiasts with a broad following. Skare has done a case study on the use of social media as a platform for communication between libraries and museums and their public. Her cases are the public library and two museums in the city of Tromsø in northern Norway.

Vårheim, Rasmussen, Jochumsen, and Rydbeck document in another chapter in this volume that although a substantial proportion of the users of libraries, archives, and museums report having used digital services during the last year, the dominating way of contacting libraries and particularly museums is via physical visits. Archives deviate from libraries and museums with a much higher proportion of the users reporting visiting the archive via Internet. Use of digital services supplement, thus, physical visits and are seldom, with archives as an exception, related to accessing content. In libraries, the dominating use is related to administering one's lending activities and in museums to checking opening hours and programs. Users of archival digital services more frequently report hav- 
ing accessed and read content digitally, for example church registers and local newspaper archives.

\section{The Structure of the Anthology}

In the following 16 chapters researchers from the ALMPUB-project will dig deeper into the problems touched upon in this introductory chapter by discussing the main findings from ALMPUB's sub projects. The anthology is organized into three parts. In the first part we focus upon policies with a main focus on those related to digitilization of the LAM field. The second part of the book contains contributions focusing upon the LAM professions. How do librarians, archivists, and museum professionals perceive their and their institutions' role as public spaces in a digital age? The third part of the book has the users as its focus area. With the exception of two chapters, the contributions in this part analyze the role libraries play in the lives of their users. One chapter in this part has a LAM perspective and one studies users in an evolving digital public space - the local history wiki.

\section{References}

Aabø, S. and R. Audunson. "Use of Library Space and the Library as Place". Library \& Information Science Research, 34, no. 2, 138-149, 2012. https://doi.org/10.1016/j.lisr.2011.06. 002.

Audunson, R. Change Processes in Public Libraries. A Comparative Project Within an Institutionalist Perspective. Doctoral dissertation, Oslo: Oslo University College, 1996.

Audunson, R. "Between Professional Field Norms and Environmental Change Impetuses. A Comparative Study of Change Processes in Public Libraries". Library and Information Science Research, 21, no. 4, 523-552, 1999.

Audunson, R. "Folkebibliotekenes rolle i en digital framtid. Publikums, politikernes og bibliotekarenes bilder (The Role of Public Libraries in a Digital Future. The Perceptions of the Public, the Politicians and the Librarians)". In Audunson, Ragnar and Niels Windfeld Lund (eds), Det sivilserte informasjonssamfunn, pp. 206-224. Bergen: Fagbokforlaget, 2001.

Audunson, R., S. Aabø, R. Blomgren, S. Evjen, H. Jochumsen, H. Larsen, C. H. Rasmussen, A. Vårheim, J. Johnston, and M. Koizumi. "Public Libraries as an Infrastructure for a Sustainable Public Sphere: A Comprehensive Review of Research". Journal of Documentation, 75, no. 4, 773-790, 2019.

Audunson, R., S. Aabø, R. Blomgren, H.-C. Hobohm, H. Jochumsen, M. Khosrowjerdi, R. Mumenthaler, K. Schuldt, C. H. Rasmussen, K. Rydbeck, M. Toth, and A. Vårheim. "Public Libraries as Public Sphere Institutions. A Comparative Study of Perceptions of the Public Library's Role in Six European Countries”. Journal of Documentation, 75, no. 6, 1396-1415, 2019.

Audunson, R., H.-C. Hobohm, and M. Toth. "LAM Professionals and the Public Sphere: How do Librarians, Archivists and Museum Professionals Conceive the Respective Roles of their Institutions in the Public Sphere?". In Audunson, R., H. Andresen, C. Fagerlid, E. Hen- 
ningsen, H.-C. Hobohm, H. Jochumsen, H. Larsen, and T. Vold (eds), Libraries, Archives and Museums as Democratic Spaces in a Digital Age. Berlin: De Gruyter Saur, 2020.

Booth, A. and A. Brice (eds). Evidence-based Practice for Information Professionals. A handbook. London, 2004.

Braman, S. Change of State. Information, Policy and Power. MIT Press, 2007.

Buschman, J. E. Dismantling the Public Sphere: Situating and Sustaining Librarianship in the Age of the New Public Philosophy. Westport, 2003.

Buschman, J. E. "The Public Sphere Without Democracy: Some Recent Work in LIS". Journal of Documentation, 2019. https://doi.org/10.1108/JD-06-2019-0115.

Byrne, A. “Democracy and Libraries. Symbol or Symbiosis?”. Library Management, 39, no. 5, 284-294, 2018.

Dreyfus, H. On the Internet. New York: Routledge, 2nd edn, 2009.

Elster, J. "States That are Essentially By-products". Social Science Information, 20, no. 3, 431473, 1981.

Engelstad, F., H. Larsen, and J. Rogstad. "The Public Sphere in the Nordic Model”. In Engelstad, F., H. Larsen, J. Rogstad, and K. Steen-Johnsen (eds), Institutional Change in the Public Sphere: Views on the Nordic Model. Berlin: De Gruyter Open, 2017.

Evjen, S. and T. Vold. "Being, Learning, Doing: A Palace for the Children? A Tween's Library Seen from the Users' Perspectives”. In Audunson, R., H. Andresen, C. Fagerlid, E. Henningsen, H.-C. Hobohm, H. Jochumsen, H. Larsen, and T. Vold (eds), Libraries, Archives and Museums as Democratic Spaces in a Digital Age. Berlin: De Gruyter Saur, 2020.

Fagerlid, C. "Democratic Coexistence, Tiny Publics and Participatory Emancipation at the Public Library”. In Audunson, R., H. Andresen, C. Fagerlid, E. Henningsen, H.-C. Hobohm, H. Jochumsen, H. Larsen, and T. Vold (eds), Libraries, Archives and Museums as Democratic Spaces in a Digital Age. Berlin: De Gruyter Saur, 2020.

Fichtelius, E., E. Enarson, K. Hansson, et al. "Den femte statsmakten. Bibliotekens roll för demokrati, utbildning, tillgänglighet och digitalisering”. Stockholm, Malmö, 2018.

Foucault, M. “Die Heterotopien. Zwei Radiovorträge [7. und 21. Dezember 1966]”. Frankfurt am Main, 2005[1966]. (French-German, bilingual edition).

Gardiner, M. E. "Wild Publics and Grotesque Symposiums: Habermas and Bakhtin on Dialogue, Everyday Life and the Public Sphere". The Sociological Review, 52, no. 1, 28-48, 2004.

Givens, L. M. and L. McTavish. "What's Old is New Again. The Reconvergence of Libraries, Archives and Museums in the Digital Age". Library Quarterly, 80, no. 1, 7-32, 2010.

Gorman, M. "Our Enduring Values Revisited. Librarianship in an Ever-Changing World". Chicago, 2015.

Habermas, J. The Structural Transformation of the Public Sphere: An Inquiry Into a Category of Bourgeois Society. Cambridge: Polity Press, 1989[1962].

Haider, J. and O. Sundin. Invisible Search and Online Search Engines. The Ubiquity of Search in Everyday Life. London: Routledge, 2019. https://doi.org/10.4324/9780429448546.

Han, B.-C. Digitale Rationalität und das Ende des kommunikativen Handelns. Berlin: Merve, 2013.

Helbing, D. The Automation of Society is Next: How to Survive the Digital Revolution. North Charleston, SC: Createspace, 2015.

Henningsen, E. and H. Larsen. "The Digitalization Imperative: Sacralization of Technology in LAM Policies”. In Audunson, R., H. Andresen, C. Fagerlid, E. Henningsen, H.-C. Hobohm, H. Jochumsen, H. Larsen, and T. Vold (eds), Libraries, Archives and Museums as Democratic Spaces in a Digital Age. Berlin: De Gruyter Saur, 2020. 
Henningsen, E. and H. Larsen. "The Joys of Wiki Work: Craftsmanship, Flow and Selfexternalization in a Digital Environment”. In Audunson, R., H. Andresen, C. Fagerlid, E. Henningsen, H.-C. Hobohm, H. Jochumsen, H. Larsen, and T. Vold (eds), Libraries, Archives and Museums as Democratic Spaces in a Digital Age. Berlin: De Gruyter Saur, 2020.

Hobohm, H.-C. "Libraries and Democracy in Germany. As Perceived by the Public in Contrast to the Professionals". In Audunson, R., H. Andresen, C. Fagerlid, E. Henningsen, H.-C. Hobohm, H. Jochumsen, H. Larsen, and T. Vold (eds), Libraries, Archives and Museums as Democratic Spaces in a Digital Age. Berlin: De Gruyter Saur, 2020.

Huysmans, F. and M. Oomes. "Measuring the Public Library's Societal Value”. IFLA Journal, 39, no. 2, 168-177, 2013.

Huzar, T. J. "The Public Library, Democracy and Rancière's Poetics of Politics”. Information Research, 18, no, 3, 2013. http://InformationR.net/ir/18-3/colis/paperC15.html.

Jaeger, P. T. and G. Burnett. "Information Worlds. Social Context Technology and Information Behavior in the Age of the Internet”. New York, 2010.

Jaeger, P. T., U. Gorham, J. C. Bertot, et al. "Democracy, Neutrality, and Value Demonstration in the Age of Austerity”. The Library Quarterly, 83, no. 4, 368-382, 2013.

Jochumsen, H. "How to Qualify the Debate on the Public Library by the Use of ResearchDeveloped Tools". Bibliothek - Forschung und Praxis, 42, no. 2, 344-350, 2018.

van Kersberger, K. Social Capitalism. A Study of Christian Democracy and the Welfare State. New York: Routledge, 1995.

Klinenberg, E. Palaces for the People. How to Build a More Equal and United Society. London: the Bodly Head, 2018.

Landemore, H. Democratic Reason: Politics, Collective Intelligence and the Rule of the Many. Princeton: Princeton University Press, 2013.

Lankes, R. D. The Atlas of New Librarianship. Cambridge, Mass.: MIT Press Association of College \& Research Libraries, 2011.

Larsen, H. "Archives, Libraries and Museums in the Nordic Model of the Public Sphere". Journal of Documentation, 74, no. 1, 187-194, 2018.

Lofland, L. A World of Strangers: Order and Action in Urban Public Space. Waveland Press, 1973.

Lyotard, J.-F. The Differend: Phrases in Dispute. Manchester: Manchester Univ. Press, 1988.

MacNeil, H. and T. M. Eastwood (eds). Currents of Archival Thinking. Santa Barbara, California: Libraries Unlimited, 2nd edn, 2017.

Marci-Boehnke, G. “Media Literacy und Librarians Beliefs. Wie Einstellungen auf das Professionalitätsverständnis wirken”. In Hauke, P. (ed.), Öffentliche Bibliothek 2030. Herausforderungen - Konzepte - Visionen, pp. 311-322. Bad Honnef, 2019.

McCall, V. and C. Gray. "Museums and the 'new Museology': Theory, Practice and Organisational Change”. Museum Management and Curatorship, 29, no. 1, 1-35, 2013. https: //doi.org/10.1080/09647775.2013.869852.

Nicholas, D. “Disintermediated, Decoupled and Down, Cilip Update”. http://ciber-research.eu/ download/20120501-CILIP_Update_March_2012_pp29-31.pdf, 2012.

Oldenburg, R. The Great Good Places - Cafés, Coffee Shops, Bookstores, Bars, Hair Salons and Other Hangouts at the Heart of a Community. New York: Marlowe \& Company, 1989.

Rancière, J. Disagreement: Politics and Philosophy. Minneapolis: Univ. of Minnesota Press, 1999. 
Rasmussen, C. H., H. Jochumsen, and D. Skot-Hansen. "Biblioteket som mødested - Sociologisk legitimitet og inspiration fra byplanlægningen”. Nordisk Tidsskrift for Informationsvidenskab og Kulturformidling, 2, no. 1, 51-59, 2013.

Schuhböck, H. P. "Die gesellschaftliche Funktion von Bibliotheken in der Bundesrepublik Deutschland. Zur neueren Diskussion nach 1945". In Bibliothek. Forschung und Praxis, 7, no. 3, 203-222, 1983.

Scott, W. R. Institutions and Organizations: Ideas, Interests, and Identities. Los Angeles: Sage, 4th edn, 2014.

Sennett, R. The Fall of Public Man. London: Penguin Books, 1977.

Sennett, R. "Quant. The Public Realm". https://www.richardsennett.com/site/senn/templates/ general2.aspx?pageid=16\&cc=gb, 2009. Accessed 19.03.2019.

Simon, N. The Participatory Museum. Santa Cruz: Museum 2.0, 2010.

Söderholm, J. and J. Nolin. "Collections Redux: The Public Library as a Place of Community Borrowing”. The Library Quarterly, 85, no. 3, 244-260, 2015.

Stalder, F. The Digital Condition. Newark: Polity Press, 2018.

Strauss, A. "Spatial Representation and the Orbits of City Life". Sociological Quarterly, 1, no. 3, 167-180, 1960.

Sunstein, C. R. Republic.com. Princeton, N.J.: Princeton University Press, 2001.

Tate, N. B. “Museums as Third Places or What?". Museums \& Social Issues, 7, no. 2, 269-283, 2012.

Vårheim, A., R. Skare, and N. Lenstra. "Examining Libraries as Public Sphere Institutions: Mapping Questions, Methods, Theories, Findings, and Research Gaps”. Library \& Information Science Research, 41, no. 2, 93-101, 2019.

Vårheim, A., C. H. Rasmussen, H. Jochumsen, and K. Rydbeck. "The Use of LAM-institutions in the Digital Age". In Audunson, R., H. Andresen, C. Fagerlid, E. Henningsen, H.-C. Hobohm, H. Jochumsen, H. Larsen, and T. Vold (eds), Libraries, Archives and Museums as Democratic Spaces in a Digital Age. Berlin: De Gruyter Saur, 2020.

Vårheim, A., R. Skare, and S. Stokstad. "Institutional Convergence and Divergence in Norwegian Cultural Policy: Central Government LAM Organization 1999-2019”. In Audunson, R., H. Andresen, C. Fagerlid, E. Henningsen, H.-C. Hobohm, H. Jochumsen, H. Larsen, and T. Vold (eds), Libraries, Archives and Museums as Democratic Spaces in a Digital Age. Berlin: De Gruyter Saur, 2020.

Widdersheim, M. M. “A Political Theory of Public Library Development”. Libri, 68, no. 4, 269289, 2018.

Widdersheim, M. M. and M. Koizumi. "Conceptual Modelling of the Public Sphere in Public Libraries”. Journal of Documentation, 72, no. 3, 591-610, 2016.

Wiegand, W. A. Part of Our Lives: A Peoples History of the American Public Library. Oxford: Oxford University Press, 2015. 